\title{
Changes to Newcomers' Psychological Contract Over Time: The Interactive Effects of the Fulfilment of Employer and Employee Obligations*
}

\author{
Cambios en el contrato psicológico de los recién llegados a lo \\ largo del tiempo: los efectos interactivos del cumplimiento de las \\ obligaciones del empleador y de los empleados
}

Received: 14 February 2016 | Accepted: 30 July 2018

\author{
Letícia Gomes Maia ${ }^{\mathrm{a}}$ \\ Banco Central do Brasil, Brazil \\ ORCID: http://orcid.org/0000-0001-5123-6724 \\ P. Matthijs Bal \\ University of Lincoln, Reino Unido \\ ORCID: http://orcid.org/0000-0002-6955-2837
}

A. Virgílio Bittencourt Bastos

Universidade Federal da Bahia, Brazil

ORCID: http://orcid.org/0000-0002-1322-5749

\begin{tabular}{lll}
\hline a Correspondence & author. & Email: \\
lgomesmaia@gmail.com & &
\end{tabular}

How to cite: Maia, L., Bal, P. M., \& Bastos, V. (2019). Changes to newcomers' psychological contract over time: The interactive effects of the fulfilment of employer and employee obligations. Universitas Psychologica, 18(1), 1-13. https://doi.org/1 0.11144/Javeriana.upsy18-1.cnpc

\begin{abstract}
The goal of this study was to examine changes in newcomers' psychological contract over time. Based on schema theory and the post-violation model of the psychological contract, we theorized that psychological contract fulfillment is strengthening the psychological contract over time, while changes in the psychological contract are most likely to occur in a situation of low employer and employee fulfillment. In a sample of newcomers in a Brazilian public organization, we tested how the fulfillment of both employer and employee obligations explain the change in the psychological contract. The results support the hypotheses, and we found that the highest level of change in psychological contracts occurred when the fulfilments of the obligations of both parties were low. We discuss the implications for theory on the change in psychological contracts.

Keywords
\end{abstract}

psychological contracts; psychological contract change; longitudinal study.

\section{RESUMEN}

El objetivo de este estudio fue examinar los cambios en el contrato psicológico de los recién llegados a lo largo del tiempo. Con base en la teoría de esquemas y el modelo post-violación del contrato psicológico, teorizamos que el cumplimiento del contrato psicológico fortalece el contrato psicológico en el tiempo, mientras que los cambios en el contrato psicológico son más probables en una situación de bajo cumplimiento del contrato psicológico. En una muestra de recién llegados en una organización pública brasileña, probamos cómo el cumplimiento de las obligaciones tanto del empleador como de los empleados explica el cambio en el contrato psicológico. Los resultados respaldan las hipótesis, y encontramos que el nivel más alto de cambio en los contratos psicológicos 
ocurrió cuando el cumplimiento de las obligaciones de ambas partes era bajo. Discutimos las implicaciones para la teoría sobre el cambio en los contratos psicológicos.

Palabras clave

contratos psicológicos; cambio de contrato psicológico; estudio longitudinal.

Understanding psychological contracts is relevant to comprehend current employeeemployer relationships, as these are changing continuously in the contemporary globalized world (Maguire, 2003). Psychological contracts are renewed constantly and adjusted over time (Rousseau, 1995). It is, therefore, not surprising that the formation of newcomers' psychological contracts and the changes over time have received a lot of attention from scholars in the field of psychological contract (see e.g., Bankins, 2015; De Vos, Buyens \& Schalk, 2003; Robinson, Kraatz \& Rousseau, 1994; Tekleab, Orvis \& Taylor, 2013). From moments of deception or pleasant surprises concerning the contract, individuals will adjust their beliefs considering the perceived reality (Louis, 1980). However, despite a growing body of research on the topic, it is still unclear how these changes in the psychological contract come about. It has been proposed that psychological contracts consist of both employer and employee obligations, and changes in psychological contracts have been primarily framed as resulting from the employer under- or over-fulfillment.

On one hand, employer fulfilment of obligations affects how employees perceive their own obligations (Coyle-Shapiro \& Kessler, 2002; De Vos et al., 2003; Robinson et al., 1994). On the other hand, employee fulfillment of obligations is likely to lead to higher expectations about the employer's obligations towards the employee (Shore \& Barksdale, 1998). More specifically, these previous studies have focused on how employee perceptions of mutual obligations decrease or increase over time (e.g., De Vos et al., 2003; Tekleab et al., 2013). While many attempts at explaining changes in psychological contracts have argued that obligations increase or decrease as a result of fulfillment (e.g., Bankins, 2015; Tomprou et al., 2015), very few studies have treated change as a deviation from stability in the contract. Hence, change as a deviation from a stable position is the focus of our current research, and theoretically, we aim to investigate how the complex interactions between employee and employer behaviors (i.e., contract fulfillments) predict whether a contract is stabilized or changes. This approach puts change as the central outcome, rather than gradual or relative decreases or increases in perceptions of obligations. This way, we offer an empirical contribution to recent theoretical debates, most notably by Tomprou, Rousseau, and Hansen (2015) and Persson and Wasieleski (2015), who theorized that radical change of the psychological contract should be contrasted to the minor, silent transformations that take place within the stability of the agreement.

In the current paper, we argue that changes in the psychological contract do not merely result from what the employer does for the employee, but from the interaction between employer and employee fulfillment of obligations in the psychological contract. Using schema theory (Sherman \& Morley, 2015) to explain how employee perceptions of mutual obligations increase as a result of fulfilments in the past, while we use the post-violation model (Tomprou et al., 2015, and Psychological Contract Theory 2.0 (Rousseau, Montes \& Tomprou, 2014) to explain that change in contrast to stability occurs in a situation of mutual withdrawal by employee and organization. We, therefore, hypothesize that the perceptions that employees have of the mutual obligations arise not only from what the employer does for them but also in comparison with what they did for their employer. We aim to contribute to psychological contract research by investigating how changes in psychological contract manifest over time, and our primary contribution is to show that psychological contracts change not only because of the lack of organizational fulfillment of obligations to the employee, but also the lack of employees' fulfillment of their part of the deal. 


\section{Psychological Contract Theory}

A central aspect in the definition of the psychological contract is the idea of exchange between employee and employer (Conway \& Briner, 2005; Rousseau, 1995). The psychological contracts involve exchanges; they are about 'deals' (Conway \& Briner, 2005). The employees perceive their own obligations toward the employer as well as the obligations of the employer towards themselves. These perceptions indicate how the content of the psychological contract develops over time, and the state of the psychological contract (Guest, 2004), whether it has been fulfilled or not. Therefore, the psychological contract refers to the perceived employer and employee obligations, and it is affected by the perception of the fulfillment of these obligations. To provide conceptual clarity in this paper, we follow the conceptualization of Rousseau (1995), which was further developed by Conway and Briner (2005) of psychological contract as consisting of employees' beliefs regarding mutual obligations between employer and employee.

We expected the psychological contract to change depending on its fulfillment over time (De Vos et al., 2003; Guest \& Conway, 2002; Lester, Kickul \& Bergmann, 2007). Hence, we study four aspects of the psychological contract: employees' perceptions of their own obligations and the employer obligations, and the employees' perceptions of fulfillment of these two types of obligations. Perceptions of mutual obligations are likely to unfold over time (De Vos et al., 2003), especially among newcomers. On the one hand, employees make sense of their psychological contracts over time, by acquiring more specific knowledge about what they can expect from their employer and what they should do for the organization (De Vos, Buyens \& Schalk, 2005). On the other hand, the individuals experience fulfillment and breaches of their psychological contract over time and adapt to these changes (Tekleab et al., 2013). Therefore, it is essential to understand the dynamics through which the psychological contract obligations develop during these first years of employment within an organization.

While previous studies have unquestionably yielded a wealth of knowledge regarding the psychological contract and its breaches, violations, and attendant antecedents and consequences (e.g., Gardody, 2016; Nisar, Liaqat, Nasir \& Ikram, 2017; Tran Huy \& Takahashi, 2017), the fact is that a basic, yet fundamental premise underlying this cumulative knowledge has remained relatively unexamined, i.e., the change in the psychological contract. In this paper, we examine the psychological contract as a dynamic process. The studies that treat the construct as a process suggest that changes in the psychological contract occur following several factors (Dabos \& Rousseau, 2004; Syrek \& Antoni, 2017; Thomas, Au \& Ravlin, 2003). The few existing longitudinal studies support the idea that newcomers change their perceptions of the psychological contract according to the reality they experience after their entry into the organization. Nevertheless, there is no consensus on the way it changes. Debode, Mossholder and Walker (2017) examined the mediating role of psychological contract fulfillment in the relationship between socialization tactics and attachment-related outcomes. Tekleab et al. (2013) examined the change in the employerbased psychological contract obligations and its relation to employee attitudes during the employee's first year of employment and found that newcomers' perceptions of employer obligations decreased over time. These findings are contradictory to the prior work of De Vos et al. (2003), Thomas and Anderson (1998), and Robinson et al. (1994). De Vos et al. (2003) found a stronger tendency to increase obligations over time. Thomas and Anderson (1998) found that employees with at least six years of service had higher expectations than the newcomers, while Robinson et al. (1994) found that newcomers expected more from their employers over the first two years of employment. Robinson et al. (1994) and De Vos et al. (2003) examined the employees' obligations. Robinson et al. (1994) found that perceived employees' obligations declined, and De Vos et al. (2003) 
found that in general, they increased. However, the general trend captured by most studies is that the perceived obligations change over time, due to sensemaking, information seeking, and changes due to breach and fulfilment (De Vos et al., 2003, 2005; Thomas \& Anderson, 1998; Tekleab et al., 2013; Robinson et al., 1994).

The psychological contract develops using recurring cycles with each party keeping or breaching their promises to the other. When people are faced with the choice of how to respond to these experiences of breach or fulfillment, they try to make sense of it in a meaningful way. Responding to a contract breach and fulfillment is essentially a sensemaking process (Louis, 1980; Weick, 1995). If promises are broken, an uncomfortable psychological dissonance leads the individual to wonder whether their perceptions need to be adjusted. Our primary interest is in the extent to which employees perceived their psychological contracts to be fulfilled and how that changed their psychological contract perceptions over time.

This study was realized with newcomers to an organization in the Brazilian public sector. Brazil was considered an appropriate context for our study because this country represents one of the emerging economies in the world, and besides its importance in the economic scenario, we have very few studies in the Brazilian context, most of them applying explorative and qualitative approaches (Rios \& Gondim, 2010). The findings of this research could be useful to other countries with some cultural similarities, such as high-power distance and collectivist values. Moreover, the public sector was appropriate because this sector has many similarities across the world, and therefore, our results are likely to hold in different contexts. Most of the studies have focused on employees of private companies (see for exceptions Cassar, 2001; Topa-Cantisano \& Caeiro, 2013). However, it is important to note that the situation of employees of public organizations offers a series of peculiar characteristics for psychological contract research, such as job security afforded. The Brazilian Constitution guarantee stability to public employees nominated for a position through means of the public entrance exam. As suggested by Vesga (2011), it is important to note that the types of employment contracts have implications in the psychological contract. Some studies compared the perceived obligations between permanent and temporary employees, and they found that permanent employees perceived the highest level of obligations in their psychological contracts (e.g., De Sousa Loreto, 2005; Silla, Gracia \& Peiró, 2005).

The position these newcomers have succeeded to obtain is considered one of the best careers in the Brazilian government. Since the organizational characteristics may affect the way the psychological contract evolves (García-Rubiano \& Forero-Aponte, 2015), it is noteworthy that this public organization, in the job market, offers comparatively high salaries, low attrition, and high job security, as long-term employment is guaranteed. Some candidates may have had the goal of just passing the selection process and enter the organization without more reflections about what would come next, because they could be mainly attracted to the job security and the comparatively high earnings, not particularly charmed by the organization.

Moreover, newcomers into this Brazilian agency would only be informed of their duties after entry into the organization. Just then, they would be informed of which department they would work in and what their activities would be. Considering this context, we expect people to be faced with experiences of breaches of the psychological contract, from both sides, themselves as employees not fulfilling their own obligations and from the perceived obligations of the employer not being met.

During the process of psychological contract adjustment, the incompatibility between a person's beliefs and the knowledge of what has been delivered motivates the person to adjust his/her beliefs and changes the perceived mutual obligations. On the other hand, if the obligations are fulfilled, there is consonance in having similar expectations for the future, which means less change to the psychological contract. The fulfillment of the employer obligations 
leads to a greater sense of commitment by the employee, because the employee and employer are engaged in an exchange relationship. When an employee perceives that the employee and employer obligations within the psychological contract are at the same level, that is, the contracting parties are similarly obligated to fulfill the contract terms, we have a balanced relationship (Shore \& Barksdale, 1998).

Accordingly, we expect a change in a psychological contract to be determined by its state of fulfillment over time (Guest \& Conway, 2002). More specifically, we employ the schema theory (Sherman \& Morley, 2015) to explain that early experiences of employees with their organizations are used to form perceptions of future exchanges and obligations. When employers are willing to fulfill the psychological contract and offer employees many inducements in the early stages of one's employment with a company, employees are likely to capture those inducements within their schema forming their employment relationship perceptions. These early experiences shape the employees' expectations about future exchanges, and hence, when employers fulfill their obligations, employees are more likely to integrate that with their beliefs. These experiences lead to a positive association between the fulfillment of obligations in the past and expectations for current and future obligations. However, this not only applies to employers' obligations but employees' obligations as well. When employees fulfill their obligations to the organization, it becomes part of their schema, of what they should contribute to their organization, and thus forms the frame of reference (Sherman \& Morley, 2015) for what they believe they should contribute to their organization.

The key contribution of this paper is to establish how psychological contracts change over time. We argue that change is likely to result from an interaction between employer fulfillment and employee fulfillment. Dabos and Rousseau (2004) investigated reciprocity, incorporating the employer's perspective and comparing the beliefs of employees and employer representatives. They found that the consistency between the two viewpoints was positively related to productivity, career advancement and intention to continue working with the employer. The employees responded to more balanced psychological contracts with work attitudes and behaviors. De Vos et al. (2003) examined the changes by the comparing promises and inducements/ contributions of one part concerning the other. Coyle-Shapiro and Kessler's (2002) findings also provide empirical support for the following hypothesis by means of positive associations between the perceived obligations of one part and the fulfillment of obligations of the other part of the psychological contract.

More specifically, we use the post-violation model (Tomprou et al., 2015), and the Psychological Contract Theory 2.0 (Rousseau et al., 2014), to explain that psychological contracts are stabilizing after the early socialization experiences of employees in their firms. After a period of stabilization, silent transformations may gradually shape psychological contracts (Persson \& Wasieleski, 2015), and hence, change in the psychological contracts functions as a deviation of a stable state. Thus, change includes the more radical deviations in employer and employee obligations over time and is expected to result from more drastic, critical events (Bankins, 2015). These significant events leading to change of the contract are not merely employer failures to deliver upon employees' expectations, but a more radical breakdown of the mutual exchange relationship between employee and organization (Tomprou et al., 2015). In line with their theorizing, change of the contract is most likely to occur when both organization and employee are unfulfilling their contract, while contracts are more likely to stabilize when both parties are fulfilling their obligations towards each other. Given our theory and the chosen context in which the employees have high expectations about the employers' obligations and not know well about their own obligations as employees, we expect to find significant results with both organization and employee unfulfilling their contract, resulting in changes of the psychological contracts. We, hence, expect that employer and employee fulfillment interact 
in predicting change, and change is more likely when the fulfillment of both is low.

Hypothesis 1. The fulfillment of employer obligations will interact with the fulfillment of employee obligations to determine the change in the perceived obligations of the employer.

Hypothesis 2. The fulfillment of employer obligations will interact with the fulfilment of employee obligations to determine the change in the perceived obligations of the employee.

\section{Method}

The population for this study consists of newcomers who passed in the competitive selection process that took place in 2010 to select civil servants for a Brazilian public sector agency. The agency has units in ten Brazilian cities and about 4,000 employees. The population is made up of 361 newcomers who share about the same date of entry to the organization. Participants were informed about this research during the orientation training. They received an invitation to participate by e-mail during the orientation training before entry $(t 1=$ Time 1 ), approximately one year after entry ( $\mathrm{t} 2)$, and about three years after entry $(\mathrm{t} 3)$. These time lags were chosen to cover the probationary period, which is three years, and which is also the mandatory term for Brazilian public civil servants to gain a permanent contract. In the invitation e-mail, a text presented the study along with an external link to the questionnaire. Participation in this study was voluntary, and the guarantee of confidentiality was declared in the invitation e-mail to the participants. The respondent did not have access to the answers of previous collections.

The first survey was filled out by 335 newcomers, 251 filled out the first and second and 202 newcomers participated in all three surveys (56 percent response rating). Twenty four employees left the organization (8 percent) during the length of this study, three were temporarily transferred to another public agency, and one had deceased. Analyses concerning change were conducted using the data from those who responded to all surveys. The mean age of respondents who participated in all surveys was 36 years, 26.7 percent was female, 34.2 percent was single and 68.1 percent had no children. It is a highly-educated population, considering that all respondents had at least a University degree and $66 \%$ some postgraduate degree. Analyses were conducted to investigate the possibility of bias produced by attrition. Comparison of the participants of the full study and those who stopped did not show any significant differences on the demographic characteristics.

The psychological contract was calibrated with the measure of Maia and Bastos (2014). The Psychological Contract Instrument consists of two Scales, the Employee obligations and the Employer obligations. We assessed the perceived employer and employee obligations at $\mathrm{t} 1, \mathrm{t} 2$, and t3. The respondents were asked to indicate for each statement to which extent they agreed, on a Likert scale ranging from $1=$ strongly disagree to $5=$ strongly agree. We assessed the fulfillment of employer and employee obligations at $t 2$ and $t 3$. The respondents were asked to rate how much they believed that their employer had fulfilled the obligations towards them and how much they believed they had fulfilled their obligations towards their employer, on a Likert scale ranging from $1=$ not at all to $5=$ totally fulfilled. All measures showed acceptable reliabilities through the times, the Cronbach's alphas for scales ranged from 0.78 to 0.87 . To confirm the construct validity, we carried out a confirmatory factor analysis on data. The model indicated a satisfactory fit for both Employer and Employee Obligations Scales over time. The data screening for unengaged responses and outliers lead to deletion of five cases.

As an analytic strategy, we conducted regression analyses for the calculated variable of change, indirectly assessed by the comparison of the obligations among times. Because it is a fivepoint scale, the differences scores ranged from -4 to 4 , in which negative values mean a decrease in perceived obligations and positive, an increase. The scale ranging from -4 to 4 was first tested, but the results were not as significant as those obtained with the absolute value of gap later 
tested, presumably due to the substantial excess of kurtosis that the resultant distribution ranging from -4 to 4 show. By choosing the absolute value gap, we obtained more robust results. Besides this, it was possible to keep the same scale for all variables, with similar meanings, just by doing the linear transformation adding 1 to all. The result was the variable of Change, ranging from $1=$ no change to $5=$ intensive change. In our analyses, we controlled for age, as this may influence the relationships under study (Bal, Lange, Jansen \& Van der Velde, 2008). As employees become older, they may become more benevolent, and thus perceiving higher obligations on their part, which has been supported in previous research (Vantilborgh, Dries, De Vos \& Bal, 2015). Finally, we analyzed the interactions between employer and employee fulfillment in predicting the change to the psychological contract. Scores were centered before interactions were calculated (Aiken \& West, 1991).

\section{Results}

Table 1 reports descriptive statistics, correlations, and Cronbach's alphas for all scales. Hypotheses were tested using hierarchical multiple regression analyses. For employer and employee obligations, controlling for the value of the same obligations in the earlier time, the relationship between the fulfillment and content of the psychological contract was assessed. A significant increase in variance explained $\left(\mathrm{R}^{2}\right)$ at the second step indicates that the fulfillment is related to a change in the psychological contract content. The interactive effects of Fulfillment of Employer and Employee Obligations in predicting changes to psychological contract over time (hypotheses 1 and 2) are reported in Table 2. Hypotheses 1 and 2 were fully supported.

\section{Table 1}

Means, standard deviations (SD), correlations, and Cronbach's alphas for the study variables

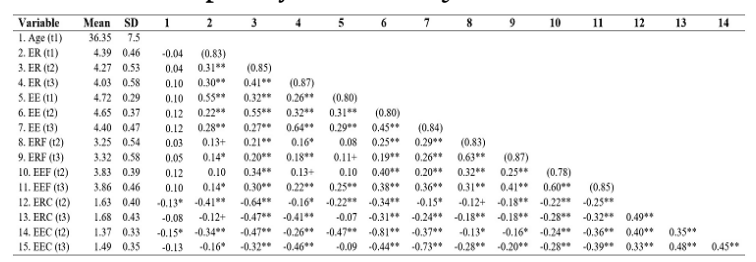

Notes.ER = Employer Obligations; EE = Employee Obligations; $\mathrm{ERF}=$ Employer Obligations Fulfilment; $\mathrm{EEF}=$ Employee Obligations

Fulfilment; ERC $=$ Employer Obligations Change; $\mathrm{EEC}=$ Employee Obligations Change. ' $\mathrm{t}$ ' before a number indicates 'Time' (e.g., $\mathrm{t} 1=$ Time1). $\mathrm{N}=240$, for Time $1 \times$ Time $2 . \mathrm{N}=197$, for Time $2 \times$ Time 3 . All the variables are expressed on a 5-point scale, except Age, Cronbach's alphas for scales appear on the diagonal parentheses. $+p<0.10, * p<0.05, * p<0.01$.

Table 2

Interaction of Fulfilment Employer and Employee Obligations predicting Psychological Contract

Change

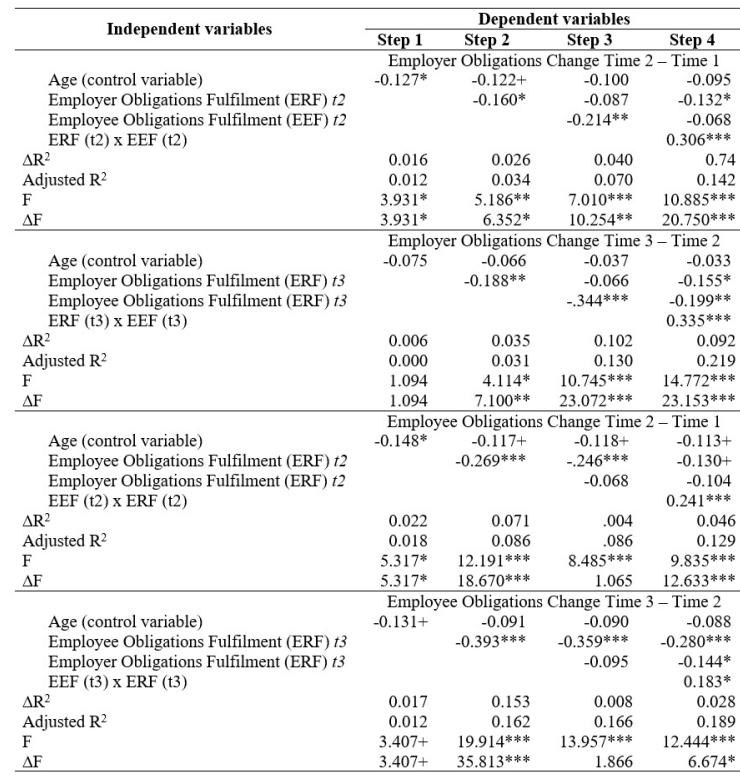

Note.Psychological contract scales were centered. Standardized regression coefficients are reported $(\beta) .+p<0.10$. $* p<0.05$. **p $<0.01$. $* * *_{p}<0.001 . \mathrm{N}=240$, for Time $1 \times$ Time $2 . \mathrm{N}=197$, for Time $2 \times$ Time 3.

The interactive effects are illustrated in Figure 1, showing that the highest level of change in Employer Obligations at Time 2 was obtained 
when both fulfilment of employer obligations and fulfilment of employee obligations were low.

\section{Figure 1}

Employer Obligations Change Time 2

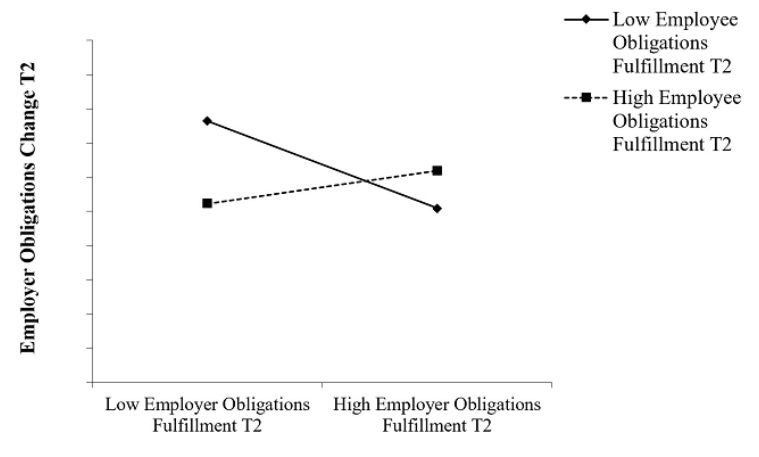

\section{Discussion}

This study investigated changes in psychological contracts during the expanded length of time of three years. The results showed that the perceived obligations decreased during the first three years of employment. These results support the findings of Tekleab et al. (2013), and the theoretical basis presented by them that point out the tendency of employees to exaggerate expectations unrealistically and to perceive the most favorable side of the organization that is hiring them (Boswell, Shipp, Payne, \& Culbertson, 2009). The results also support the findings of Robinson et al. (1994), which pointed to a decrease in employee's obligations over the first two years of employment.

The direction of change in the perceptions of obligations is an interesting point of the findings of this research, conducted in the public sector, which offers stability, security, and wellestablished rules, because it is evidence that the psychological contract and the perceived obligations go beyond and above the call of duty and the general terms of the formal job contracts. There is a great awareness of the legal contract, i.e., the terms of working hours, benefits, payments and job stability, however, there is a series of intangibles, of things that cannot be touched or counted, and that the new employees can hardly imagine. The frame time of three years and the methodological rigor applied, allow us to affirm with security that the obligations perceived by the employees became less over the years. What made them change their perceptions? In this paper, we found that the fulfillment of the psychological contract is one of the reasons to change it. Moreover, that it is not only about the employer obligations, but also about the employee obligations. This is the main point of this research that a contract has at least two sides, and both sides together affect how the psychological contract changes.

This research advances theory by adding back the employee side of the psychological contract and therefore, can investigate how the perceptions of fulfillment of the employee obligations interact with the perceptions of fulfillment of the employer obligations to predict change. This is the main implication of our findings for the theoretical models on psychological contract. As discussed previously, the literature so far lacks more longitudinal studies to investigate both types of obligations, those on the part of the employer and those on the part of the employee during the process of the development of the psychological contract. Our results suggest that for both employer and employee there is a fit process derived from the comparison between a person's beliefs of what had been promised and the knowledge of what had been done for real. Nevertheless, the propensity for balancing the employeremployee exchange relationship also exerted an influence on how their perception of obligations changes. Our results showed that employees react according to what they receive, and that their actions depend on whether the employer fulfills its obligations. Our findings strengthen the argument of De Vos et al. (2003), and CoyleShapiro and Kessler (2002).

In the analyses of the hypotheses, we found that lower levels of fulfillment of both sides in the psychological contract, employer and employee, predicted the most significant changes. The importance of the balance for the psychological contracts is pointed out by the lines in the plots that represent the high fulfillment of the obligations of the other part in the psychological contract. Although the fulfillment of these 
obligations influences the perceived employer obligations, they are more strongly influenced by the belief of the employee if he/she is or is not complying with his/her own obligations to the employer. Likewise, although the employees perceive their own obligations depending on if they had fulfilled them, the perception of their own obligations depends more on if the employer had met its obligations to them.

The issue of psychological contract development and change remained relatively unexamined, while we have significantly advanced research on psychological contract breaches, violations, and consequences. By examining the perceived employee obligations, our findings suggest that change in the psychological contract can be a critical index which reveals how the individual alters his or her actions within or toward the organization. More specifically, we have added to the better understanding of how change occurs in psychological contracts and thereby advancing recent work on them, such as the post-violation model (Tomprou et al., 2015). The changes in psychological contracts are most likely to occur when the employer and the employee withhold their contributions to the relationship. While low levels of employer fulfillment may arouse negative emotions (Bankins, 2015), it does not necessarily destabilize the contract, and it only happens when employees respond by lowering their efforts that change will occur in the psychological contract, potentially creating a negative spiral which is difficult to repair (Solinger, Hofmans, Bal \& Jansen, 2015).

This is among the first studies to show the interaction between fulfillment of employer and employee obligations to explain the change in the psychological contract over time. This article adds to previous studies (Coyle-Shapiro \& Kessler, 2002; Dabos \& Rousseau, 2004; De Vos et al., 2003; Lester et. al., 2007; Robinson et al., 1994; Tekleab et al., 2013; Thomas \& Anderson, 1998) by the study of the interactive effects of employer and employee fulfilment obligations for the explanation of change. The perceptions that the employees have of the mutual obligations arise not only from what the employer does for them but also in comparison with what they did for their employer together. Our results show that the most substantial changes in the psychological contract were more likely to occur when not only the employer fails to fulfill its obligations, but also when the employee does not deliver his/her part of the deal.

Considering that pre-employment experiences can be considered antecedents of the psychological contract and can collaborate to its formation and that this study was conducted with newcomers, these findings suggest useful implications for organizational practice. They provide an interesting way to understand better how employees form their psychological contracts and the potential consequences that may result from the failure in communicating what can be expected from the employer. The manager can expect the newcomer to change his/her perception of what obligations he/she has about the organization depending on the level at which the organization fulfills its part of the deal, as expected by him/her. Reminding that these newcomers may have had high expectations about the employer, being this organization one of the best careers in the Brazilian government we can easily understand why the perception about the fulfillment of the employer obligations was not high. Moreover, the perceived employer obligations decreased over time. Recovering the information that the newcomers would only be informed of their duties after entry into the organization, we can easily understand as well why the perception about the fulfillment of the own obligations was not high either, and the perceived employer obligations also decreased over time. Both obligations were adjusted face reality after entering the organization, and the perceived obligations decreased in general. In those situations that the fulfillment of the obligations of both sides in the psychological contract was low, the psychological contract changed significantly, as a consequence.

The changing psychological contract is neither good nor bad in itself, but it reflects a process of adaptation. This change may have negative consequences for the organization if it induces breach or violation in the psychological contract 
as a vast amount of research demonstrates (Robinson \& Morrison, 2000; Turnley \& Feldman, 1999). Therefore, it is important to pay attention to the first contacts with the organization, from the initial experience, such as recruiting, selection processes and the first socialization periods, to avoid potential breaches resulting in misunderstandings. Above all, the main practical implication of our findings is that managers should be advised not to expect employees to perceive their own obligations at a higher level if the obligations of the organization are not being fulfilled at an equivalent level as well.

The results of the current study suggest that as important as letting the employees understand what is expected from them to achieve the organizational goals, is to listen and understand what the employees expect from the organization in return. It is important to listen to their expectations and try to balance the psychological contract. The organizations may increase the level of employee obligations through investing specific inducements, which are offered to the employees in order to enhance their contributions. However, it is also important for organizations to realize that employee obligations are not merely the result of what the organization does for the employee, but also the extent to which employees have had the chance to contribute to the organization.

\section{Limitations and suggestions for future research}

Despite the suitableness of a longitudinal research design to investigate a dynamic construct, there are some limitations related to this design, such as common method biases. The ideal situation to reduce these biases would be obtaining measures of the employer and employee obligations from different sources. Someone representing the organization could have evaluated the employees' side. However, when it is not possible to obtain data from different sources, one potential remedy is to separate the measurement of variables by introducing a time lag between them. The variable of Change, indirectly assessed by the comparison of the obligations among times, represents an unbiased estimate of change since the respondents did not have access to the answers of previous collections. Selfreported measures might also cause socially desirable responses when measuring employees' evaluations of their promises and fulfillment. Future research should address these issues. The characteristics of the research sample, from only one public organization in Brazil, limits the possibility of generalizing the findings. Therefore, it is yet unclear whether the results of the current study can be generalized to other cultural contexts. Further research is needed for validation of the reported findings within a broader population and in different cultural contexts.

\section{Conclusion}

This study supports the conceptualization of the psychological contract as a process. It points out that the changes in the psychological contract depend on its fulfillment. The main contribution of this article is to address the issue of changes in psychological contracts over time. Overall, this research suggests that the psychological contract goes through an adjustment period, changing a function of adaptation and balance in the experiences encountered after entry. Especially when there is low fulfillment by both parties, change is most likely to occur. These findings provide an insight into the process of the formation of the psychological contract and suggest useful implications for organizational practice.

\section{Acknowledgements}

This work was supported by the Coordination for the Improvement of Higher Education Personnel (CAPES), under grant 9480/12-9. This work was also supported by the Conselho Nacional de Desenvolvimento Científico eTecnológico (CNPq) under grant 476160/2011-1. We are 
grateful to the reviewers whose constructive comments strengthened this paper. The views expressed in this paper are those of the authors and are not necessarily reflective of views at the Banco Central do Brasil (Central Bank of Brazil).

\section{References}

Aiken, L. S., \& West, S. G. (1991). Multiple regression: Testing and interpreting interactions. Newbury Park: Sage.

Bal, P. M., Lange, A. H., Jansen, P. G. W., \& Van der Velde, M. E. G. (2008). Psychological contract breach and job attitudes: a metaanalysis of age as a moderator. Journal of Vocational Behavior, 72, 143-158. https://do i.org/10.1016/j.jvb.2007.10.005

Bankins, S. (2015). A process perspective on psychological contract change: Making sense of, and repairing, psychological contract breach and violation through employee coping actions. Journal of Organizational Behavior, 36(8), 1071-1095. https://doi.org/10.1002/job.2007

Boswell, W. R., Shipp, A. J., Payne, S. C., \& Culbertson, S. S. (2009). Changes in newcomer job satisfaction over time: Examining the pattern of honeymoons and hangovers. Journal of Applied Psychology, 94, 844-858. https://doi.org/10.1037/a0014975

Cassar, V. (2001). Violating psychological contract terms among Maltese public service employees: occurrence and relationships. Journal of Managerial Psychology, 16, 194-208. Retrieved from https://www.ingentaconnect.com/con tent $/ \mathrm{mcb} / 050 / 2001 / 00000016 / 00000003 / \mathrm{a}$ rt00001

Conway, N., \& Briner, R. B. (2005). Understanding psychological contracts at work: A critical evaluation of theory and research. Oxford Scholarship Online. https://doi.org/10.1093/acprof:oso/ 9780199280643.001.000

Coyle-Shapiro, J. A. M., \& Kessler, I. (2002). Exploring reciprocity through the lens of psychological contract: Employee and employer perspectives. European Journal of Work and Organizational Psychology, 11(1), 69-86. https://doi.org/10.1080/1359432014 3000852

Dabos, G. E., \& Rousseau, D. M. (2004). Mutuality and reciprocity in the psychological contracts of employees and employers. Journal of Applied Psychology, 89(1), 52-72. https://doi.org/10.1080/10.10 37/0021-9010.89.1.52

Debode, J., Mossholder, K., \& Walker, A. (2017). Fulfilling employees' psychological contracts: organizational socialization's role. Leadership $\mathcal{E}$ Organization Development Journal. 38(1), 42-55. https://doi.org/10.11 08/LODJ-02-2015-0014

De Vos, A., Buyens, D., \& Schalk, R. (2003). Psychological contract development during organizational socialization: Adaptation to reality and the role of reciprocity. Journal of Organizational Behavior, 24(5), 537-559. ht tps://doi.org/10.1002/job.205

De Vos, A., Buyens, D., \& Schalk, R. (2005). Making sense of a new employment relationship: Psychological contract-related information seeking and the role of work values and Locus of Control. International Journal of Selection and Assessment, 13(1), 41-52. https://doi.org/10.1111/j.0965-075X .2005.00298.x

De Sousa Loreto, C. (2005). Estudio comparativo del contrato psicológico en empleados temporales y permanentes (Tesis de pregrado). Universidad Católica Andrés Bello, Venezuela.

García-Rubiano, M., \& Forero-Aponte, C. (2015). Contrato psicológico y cambio organizacional en una entidad perteneciente al sector terciario de la ciudad de Bogotá, Colombia. Revista de Investigación, Desarrollo e Innovación, 6(1), 15-28. https://doi.org/10.19053/20278306. 4047

Gardody, J. (2016). La formation et la violation $\mathrm{du}$ contrat psychologique: quels processus cognitifs? RIMHE: Revue Interdisciplinaire Management, Homme $\mathcal{E}$ Entreprise, 5(29), 
Letícia Gomes Maia, P. Matthijs Bal, A. Virgílio Bittencourt Bastos.

3-26. Retrieved from http://hal.univ-reunio n.fr/hal-01651601

Guest, D. (2004). The psychology of the employment relationship: an analysis based on the psychological contract. Applied Psychology: An International Review, 53(4), 541-555. https://doi.org/10.1111/j.1464-05 97.2004.00187.x

Guest, D., \& Conway, N. (2002). Communicating the psychological contract: an employer perspective. Human Resource Management Journal, 12(2), 22-38. https://doi.org/10.1111/j.1748-8583 .2002.tb00062.x

Lester, S. W., Kickul, J. R., \& Bergmann, T. J. (2007). Managing employee perceptions of the psychological contract over time: The role of employer social accounts and contract fulfilment. Journal of Organizational Behavior, 28(2), 191-208. ht tps://doi.org/10.1002/job.410

Louis, M. R. (1980). Surprise and sense making: What newcomers experience in entering unfamiliar organizational settings. Administrative Science Quarterly, 25, 226-251. Retrieved from http://bernard. bianca.pivot.free.fr/Articles/Socialisation\% 20Organisationnelle/Louis\%20(1980).pdf

Maguire, H. (2003). The changing psychological contract: challenges and implications for HRM, organisations and employees. In R. Wiesener \& B. Millett (Eds.), Human resource management: challenges and future directions (pp. 87-103). Queensland: John Wiley \& Sons.

Maia, L. G., \& Bastos, A. V. B. (2014). Validação de instrumento de contrato psicológico. Avaliação Psicológica, 13(3), 409-417. Retrieved from http://pepsic.bvsa lud.org/pdf/avp/v13n3/v13n3a13.pdf

Nisar, Q., Liaqat, I., Nasir, M., \& Ikram, M. (2017). The crucial role of psychological contracts towards organizational behaviors: Descriptive study in banking sector. International Journal for Research in Social Science and Humanities, 3(6), 1-15.

Persson, S., \& Wasieleski, D. (2015). The seasons of the psychological contract: Overcoming the silent transformations of the employeremployee relationship. Human Resource Management Review, 25(4), 368-383. https: //doi.org/10.1016/j.hrmr.2015.02.003

Rios, M. C., \& Gondim, S. M. G. (2010). Contrato psicológico de trabalho e a produção acadêmica no Brasil. Revista Psicologia Organizações e Trabalho, 10(1), 23-36. Retrieved from http://pepsic.bvsalud.org/pdf/rpot/ v10n1/v10n1a03.pdf

Robinson, S. L., \& Morrison, A. E. W. (2000). The development of psychological contract breach and violation: a longitudinal study. Journal of Organizational Behavior, 21, 525-546. Retrieved from http://citeseerx.ist.psu.edu/viewdoc/d ownload?doi $=10 \cdot 1 \cdot 1 \cdot 458.7023 \&$ rep $=$ rep 1 \&type $=\mathrm{pdf}$

Robinson, S. L., Kraatz, M. S., \& Rousseau, D. M. (1994). Changing obligations and the psychological contract: a longitudinal study. Academy of Management Journal, 37(1), 137-152. http://dx.doi.org/10.2307/ 256773

Rousseau, D. M. (1995). Psychological contracts in organizations: understanding written and unwritten agreements. Thousand Oaks, California: Sage.

Rousseau, D. M., Montes, S. D., \& Tomprou, M. (2014). Psychological contract theory 2.0. Unpublished manuscript.

Sherman, U. P., \& Morley, M. J. (2015). On the formation of the psychological contract a schema theory perspective. Group $\mathbb{E}$ Organization Management, 40, 160-192. htt ps://doi.org/10.1177/1059601115574944

Shore, L. M., \& Barksdale, K. (1998). Examining degree of balance and level of obligation in the employment relationship: A social exchange approach. Journal of Organizational Behavior, 19(Spec Issue), 731-744. http://dx.doi.org/10.1002/ (SICI) 1099-1379(1998) 19:1+<731::AID JOB969>3.0.CO;2-P

Silla, I., Gracia, F., Gracia, F., \& Peiró, J. (2005). Diferencias en el contenido del contrato psicológico en función del tipo de 
contrato y de la gestión empresarial pública o privada. Revista de Psicología Social, 20(1), 61-72. http://dx.doi.org/10.1174/02134740 52871097

Syrek, C., \& Antoni, C. (2017). Psychological contract fulfillment and employee responses to pay system change: The effects of transformational leadership. Journal of Personnel Psychology, 16(4), 172-185. http:/ /dx.doi.org/10.1027/1866-5888/a000186

Solinger, O. N., Hofmans, J., Bal, P. M., \& Jansen, P. G. W. (2015). Bouncing back from psychological contract breach: How commitment recovers over time. Journal of Organizational Behavior, 37(4), 494-514. ht tps://doi.org/10.1002/job.2047

Tekleab, A. G., Orvis, K. A., \& Taylor, M. S. (2013). Deleterious consequences of change in newcomers' psychological contracts. Journal of Business and Psychology, 28(3), 361-374. http://dx.doi.org/10.1007/s 10869-012-9277-2

Thomas, D. C., Au, K., \& Ravlin, E. C. (2003). Cultural variation and the psychological contract. Journal of Organizational Behavior, 24(5), 451-471. https://doi.org/10.1002/job .209

Thomas, H. D. C., \& Anderson, N. (1998). Changes in newcomers' psychological contracts during organizational socialization: A study of recruits entering the British Army. Journal of Organizational Behavior, 19(1), 745-767. https://doi.org/10.1002/ (SICI) 1099-1379(1998) 19:1+<745::AIDJOB967>3.0.CO;2-I

Tomprou, M., Rousseau, D. M., \& Hansen, S. D. (2015). The psychological contracts of violation victims: A post-violation model. Journal of Organizational Behavior, 36(4), 561-581. https://doi.org/10.1002/job.1997

Topa-Cantisano, G., \& Caeiro, J. L. (2013). Gestión de recursos humanos y empleo público: un estudio cuantitativo con funcionarios del Estado en España. Revista de Psicología, Ciències de l'Educació $i$ de l'Esport, 31(2), 35-43. Retrieved from http://www.revistaaloma.net/index.p hp/aloma/article/view/203

Tran Huy, P. \& Takahashi, K. (2017). Determinants of psychological contract breach: An empirical study of Vietnamese employees. Management Research Review, 41 (1), 29-45. https://doi.org/10.1108/MRR $-11-2016-0244$

Turnley, W. H., \& Feldman, D. C. (1999). The impact of psychological contract violations on exit, voice, loyalty, and neglect. Human Relations, 52 (7), 895-922. https://doi.org/10 $.1177 / 001872679905200703$

Vantilborgh, T., Dries, N., De Vos, A., \& Bal, P. M. (2015). The psychological contracts of older employees. In $\mathrm{P}$. M. Bal, D. T. A. M. Kooij, \& D. M. Rousseau (Eds.), Aging Workers and the Employee-Employer Relationship (pp. 107-127). London: Springer International Publishing.

Vesga, J. J. (2011). Los tipos de contratación laboral y sus implicaciones en el contrato psicológico. Pensamiento Psicológico, 9(16), 171-181.

Weick, K. E. (1995). Sensemaking in organizations. Thousand Oaks, CA: Sage.

\section{Notes}

* Research article. 